\title{
The [4Fe4S] Cluster of Human DNA Primase functions as a Redox Switch using DNA Charge Transport
}

\author{
Elizabeth O'Brien ${ }^{1}$, Marilyn E. Holt ${ }^{2}$, Matthew K. Thompson², Lauren E. Salay², Aaron C. \\ Ehlinger ${ }^{2}$, Walter J. Chazin ${ }^{2,}$, and Jacqueline K. Barton ${ }^{1,{ }^{*}}$ \\ ${ }^{1}$ Division of Chemistry and Chemical Engineering, California Institute of Technology, Pasadena, \\ CA 91125 \\ ${ }^{2}$ Departments of Biochemistry and Chemistry, Center for Structural Biology, Vanderbilt University, \\ Nashville, TN 37235
}

\begin{abstract}
DNA charge transport chemistry offers a means of long range, rapid redox signaling. Here we demonstrate that the [4Fe $4 \mathrm{~S}$ ] cluster in human DNA primase can utilize this chemistry to coordinate the first steps of replication. Through DNA electrochemistry, we find that a change in oxidation state of the [4Fe4S] cluster acts as a switch for DNA binding. Single-atom mutations that inhibit this charge transfer, moreover, hinder primase initiation without affecting primase structure or polymerization. Generating a single base mismatch in the growing primer duplex, which attenuates DNA charge transport, inhibits primer truncation. Thus redox signaling by [4Fe4S] clusters using DNA charge transport regulates primase binding to DNA and illustrates chemistry that may efficiently drive substrate handoff between polymerases during DNA replication.
\end{abstract}

\section{One Sentence Summary}

The [4Fe4S] cluster in DNA primase is a redox switch for DNA binding, using DNA charge transport to initiate primer synthesis and facilitate primer handoff.

The ability of DNA to transport charge over long range represents an intriguing potential regulatory mechanism in biology. DNA charge transport (DNA CT) provides a rapid means of signaling among redox moieties coupled into the DNA duplex, as well as a mechanism to sense the integrity of DNA (1-6). Remarkably, [4Fe4S] clusters, inorganic cofactors often associated with biological redox chemistry $(7,8)$, are now being identified in proteins involved in DNA replication (9-17). The eukaryotic DNA primase enzyme responsible for initiation of replication on single-stranded DNA, for example, is a [4Fe4S] cluster enzyme. The [4Fe4S] cluster in primase has been shown to be essential for activity (9-16), but the role of this cofactor was unclear.

Rapid and accurate copying of genomic DNA in humans and other higher eukaryotes is the product of high fidelity, processive, replicative DNA polymerases (18-21). While efficient,

Correspondence to: jkbarton@caltech.edu and walter.j.chazin@vanderbilt.edu. 
these enzymes are unable to initiate synthesis of the new complementary strand without a short primer on the single-stranded DNA (ssDNA) template. The task of initiating synthesis of the new DNA strand is the responsibility of a heterotetrameric complex of two specialized polymerases: DNA primase and DNA polymerase a (pol a), both of which were discovered to contain [4Fe4S] clusters $(9-11,17)$. Primase, a DNA-dependent RNA polymerase, generates an initial 8-12 nucleotide RNA primer on ssDNA before handing the nascent primer-template off to pol $\mathrm{a}$, which extends the primer by 20 DNA bases before handoff to the more processive polymerases ( ${ }^{\mathrm{TM}}$ and $\Sigma$ ). X-ray crystal structures have been determined for all globular domains of primase and pol $a$ as well as for the primase heterodimer and the heterotetrameric pol-a-primase (pol-prim) complex (11, 16, 22-25). However, limited structural data have been obtained about catalytically active conformations and architectural changes in the pol-prim tetramer as the primer is initiated, elongated first by primase then by pol $\alpha$, and subsequently handed off to a processive polymerase. In particular, although the mechanism and structure of the catalytic subunit of primase have been extensively studied $(15,16,26,27)$, the chemistry behind primase transferring a nascent primer to pol $a$ is poorly understood.

Eukaryotic primases are heterodimeric, composed of a catalytic subunit (p48) and a regulatory subunit (p58) $(28,29)$. The regulatory subunit contains a C-terminal domain (p58C) that is unique to eukaryotes and contains the [4Fe4S] cluster cofactor required for efficient priming (10). The biochemical evidence of the role for the [4Fe4S] cluster in primase, in addition to the high energetic cost (8) paid by cells to assemble and load this cofactor into an enzyme, argues for a functional rather than structural role for the cofactor (30).

\section{DNA-Mediated Electrochemistry}

To study the DNA-bound redox properties of enzymes with [4Fe4S] clusters, we employ DNA-mediated electrochemistry, a robust method for directly measuring DNA CT in the ground state $(5,31,32)$ (Figure 1A, 1B). An alkanethiol-terminated, annealed duplex DNA (dsDNA) substrate is deposited on a gold surface, facilitating covalent linkage of the DNA to the gold through the thiol moiety. The gold is passivated using $\beta$-mercaptohexanol and becomes the working electrode in a three-electrode cell, with an external $\mathrm{Ag} / \mathrm{AgCl}$ reference electrode and a platinum counter electrode $(5,31,32)$. Charge transport through the stacked bases of dsDNA between the gold surface and a redox-active species bound at the distal end of the DNA can be measured using this platform under solution conditions. Cyclic voltammetry $(\mathrm{CV})$ is employed to measure changes in current over a range of applied potentials. Earlier electrochemical studies of the base excision repair glycosylase Endonuclease III (EndoIII) using CV have shown that binding of the protein to the DNA polyanion shifts the redox potential of the $[4 \mathrm{Fe} 4 \mathrm{~S}]$ cluster $200 \mathrm{mV}$ negative to $\sim 80 \mathrm{mV}$ vs. NHE, into the physiological range of cellular potentials, activating the cluster for redox chemistry $(2,33)$. Importantly, this potential shift corresponds thermodynamically to a 1000fold increase in DNA binding affinity for the oxidized [4Fe $4 \mathrm{~S}]^{3+}$ state of EndoIII relative to the reduced $[4 \mathrm{Fe} 4 \mathrm{~S}]^{2+}$ state. 


\section{Oxidized and Reduced p58C Electrochemistry}

The p58C domain of human DNA primase, independently of the rest of the enzyme, binds a primed template DNA (Table S1) with modest affinity $\left(\mathrm{K}_{\mathrm{d}}=5.5 \pm 0.5 \mu \mathrm{M}\right)$ when initially present as isolated in the reduced, EPR-silent $[4 \mathrm{Fe} 4 \mathrm{~S}]^{2+}$ state $(9,10)$ (Figure S1). To investigate whether the p58C [4Fe4S] cluster oxidation state affects DNA binding, as observed in Endonuclease III (2), we used DNA electrochemistry. Experiments are carried out using a sixteen-electrode multiplexed chip, which allows for robust, reproducible, and internally consistent measurements of various conditions on a single surface (Figure 1A) $(5,6,31-33)$. Bulk electrolysis is used to convert a sample to a uniform redox state in this setup, and it is performed by passage of current through the DNA at a constant applied potential. This technique facilitates the oxidation or reduction of the DNA-bound protein with a direct transfer of electrons through the DNA, eliminating the need for exogenous chemical oxidants or reductants that could damage the protein.

For DNA electrochemistry on p58C, an alkane-thiol modified primed template DNA substrate (Table S1) was used. All experiments are performed in an anaerobic environment with deoxygenated reagents to prevent atmospheric cluster oxidation (34) and to ensure control of the redox state of the p58C samples on the electrode. As in earlier studies (2), we confirmed that $\mathrm{p} 58 \mathrm{C}$ electrochemistry is DNA-mediated by observing a reversible p58C CV signal in the presence of ATP, which is attenuated when an intervening abasic site perturbs the base stacking of the duplex DNA substrate (Figure S2). The reversible redox signal observed when p58C is bound to both DNA and ATP is likely a result of the p58C [4Fe4S] cluster being better coupled into the DNA duplex for CT when bound to DNA and a nucleotide triphosphate (NTP), both necessary substrates for primase activity; the improved coupling likely is the result of a conformational change. Increased coupling of the [4Fe4S] cluster to duplex DNA was previously observed for the [4Fe4S] helicase XPD ( $S$. acidocaldarius) upon binding ATP, a substrate necessary for XPD activity. (35)

To electrochemically assay p58C in the presence of DNA only, oxidized and reduced samples are generated and subsequently compared on a single surface using bulk electrolysis followed by CV scanning. By passing sufficient current through the DNA-modified electrode at an oxidizing (412 $\mathrm{mV}$ vs. NHE) or reducing ( $-188 \mathrm{mV}$ vs. NHE) potential, p58C is converted to the desired redox state (Figure 1B, Figure S3). We observe no redox signal by $\mathrm{CV}$ for electrochemically unaltered $\mathrm{p} 58 \mathrm{C}$, indicating that the EPR-silent, $[4 \mathrm{Fe} 4 \mathrm{~S}]^{2+}$ protein obtained upon isolation $(9,10)$ is not electrochemically active on DNA (Figure S4). After oxidation by bulk electrolysis, however, a large cathodic peak between -130 and $-140 \mathrm{mV}$ vs. NHE appears in CV (100 mV/s scan rate) during the initial scan to negative potentials (Figure 1C). Importantly, the electrochemical signal through DNA is lost after scanning to reducing potentials. The signal observed in the $\mathrm{CV}$ scan to negative potential for the oxidized p58C sample corresponds to a reduction event, which we assign to the electron transfer reaction in which the tightly bound, electrochemically active $[4 \mathrm{Fe} 4 \mathrm{~S}]^{3+}$ $\mathrm{p} 58 \mathrm{C}$ is converted to a more weakly associated, electrochemically inactive $[4 \mathrm{Fe} 4 \mathrm{~S}]^{2+}$ state. Consistent with this observation, $\mathrm{CV}$ after reduction displays no redox signal (Figure 1D), as observed initially for the native protein, which we attribute to the lower affinity for DNA of the $[4 \mathrm{Fe} 4 \mathrm{~S}]^{2+}$ state. 
To confirm assignment of the $\mathrm{p} 58 \mathrm{C}$ redox signal, we employed iterative cycles of $\mathrm{p} 58 \mathrm{C}$ electrochemical oxidation on a single electrode surface, followed each time by $\mathrm{CV}$ scanning (Figure 2A). If scanning to negative potentials reduces the tightly bound $[4 \mathrm{Fe} 4 \mathrm{~S}]^{3+} \mathrm{p} 58 \mathrm{C}$ coupled to the DNA duplex for $\mathrm{CT}$, to the weakly bound, uncoupled $[4 \mathrm{Fe} 4 \mathrm{~S}]^{2+}$ state, a second oxidation of the same sample should convert p58C again to the $[4 \mathrm{Fe} 4 \mathrm{~S}]^{3+}$ state and regenerate the $\mathrm{CV}$ signal as the protein rebinds tightly to the DNA. We performed five sequential bulk electrolysis reactions on a single electrode surface, followed each time by $\mathrm{CV}$ scanning $(100 \mathrm{mV} / \mathrm{s})$. We found each time that the $\mathrm{p} 58 \mathrm{C}$ redox signal was not present after reduction during $\mathrm{CV}$. However, upon conversion from the reduced to the oxidized state, the CV signal was regenerated. During the initial scan after oxidation, a cathodic peak between -130 and $-140 \mathrm{mV}$ vs. NHE (100mV/s scan rate) consistently appears (Figure $2 \mathrm{~B}$ ). This reversible behavior suggests that the oxidation state of the $[4 \mathrm{Fe} 4 \mathrm{~S}]$ cluster alters DNA binding by $\mathrm{p} 58 \mathrm{C}$; tighter DNA binding is associated with oxidation.

Progressively larger CV signals appear with each iterative oxidation performed under identical electrolysis conditions. The change in CV signal under constant oxidation conditions suggests that oxidation brings more molecules of p58C to the DNA substrate on the electrode each time that electrolysis is performed (Figure S5). Previously oxidized p58C molecules, together with newly oxidized p58C generated during each electrolysis at $412 \mathrm{mV}$ vs. NHE, appear in the CV signal obtained after each oxidation. Moreover, it is not feasible on our experimental timescale that two serial protein diffusion events, diffusion of previously oxidized p58C molecules away from the DNA, followed by diffusion of a new sample to the DNA replacing them, can occur. This evidence therefore strongly suggests that the redox switch in the oxidation state of the $[4 \mathrm{Fe} 4 \mathrm{~S}]$ cluster modulates DNA binding and coupling of the $[4 \mathrm{Fe} 4 \mathrm{~S}]$ cluster into the DNA duplex for CT. The molecular basis for how oxidation controls this increase in DNA affinity is not known; progress to define this mechanism has been inhibited by the inability to produce sufficient quantities of uniformly oxidized, $[4 \mathrm{Fe} 4 \mathrm{~S}]^{3+} \mathrm{p} 58 \mathrm{C}$. Part of the increase in DNA affinity is likely electrostatic in origin, associated with the oxidized protein being bound to the DNA polyanion. It is also likely, however, that a conformational change is associated with oxidation.

\section{Charge Transfer Pathway through p58C}

Iterative, electrochemically controlled oxidation and reduction cycles demonstrate the ability of p58C to switch between weak and tight DNA binding upon a change in the oxidation state of the [4Fe4S] cluster under the control of DNA-mediated CT through the DNA electrode. For this DNA-mediated redox switch reaction to occur, however, a tunneling pathway (36) through p58C is necessary to move charge the $\sim 25 \AA$ distance between the primed template DNA binding site and the $[4 \mathrm{Fe} 4 \mathrm{~S}]$ cluster cofactor $(11,22)$. Residues within p58C must therefore shuttle charge through the insulating protein matrix to mediate the DNA binding switch reaction. In order for the protein-mediated redox reactions to occur on a feasible timetable over these distances, it is critical that residues with a low ionization potential are present in the electron transfer pathway (36-38). Tyrosine residues, whose aromatic rings can stabilize protein radicals, serve as redox mediators in a variety of proteins (39). Moreover, conservation of tyrosine residues across $\mathrm{p} 58 \mathrm{C}$ domains of eukaryotic primases suggests potential participants in such a CT pathway through the protein to the DNA 
interface. In all structures of human p58C, three conserved tyrosine residues (Y309, Y345, Y347) form a pathway from the cluster to the putative DNA binding surface (Figures 3A, S6B). Given its low ionization energy of $8.5 \mathrm{eV}$ in solution relative to $9.4 \mathrm{eV}$ for phenylalanine (39) and an average of $\sim 9.6 \mathrm{eV}$ (36) for aliphatic residues, tyrosine is able to mediate electron/hole transfer through proteins; the phenol side chain of tyrosine can more easily hold a radical than aliphatic residue side chains. Tyrosine residues have additionally been shown to mediate hopping reactions through other proteins to facilitate biological redox chemistry. (36) The chain of tyrosines in p58C is additionally within a feasible range for tunneling (36) between bound DNA and the [4Fe4S] cluster. For these reasons, the three conserved tyrosines in $\mathrm{p} 58 \mathrm{C}$ were viewed as a likely conduit to facilitate electron transfer from the cluster to the DNA.

To test the proposed CT pathway, we designed and isolated three human p58C Y-F variants (Y309F, Y345F, Y347F), which were characterized in the same manner as the wild type protein. All three mutants are loaded with [4Fe4S] cluster to a similar degree as WT, as reflected in the UV-Visible absorbance $280 \mathrm{~nm} / 410 \mathrm{~nm}$ ratio. To validate proper folding of the Y-F variants, circular dichroism was used to establish that the distribution of secondary structure is essentially identical to wild type (Figure S7). We also determined an X-ray crystal structure of p58C Y345F (Table S2, Figure S8). The presence of the cluster in the mutant and the RMSD from the wild type protein of only $0.22 \AA$ for the Y345F variant confirms that the structure is not perturbed. Critically, the crystal structure reveals that the F345 aromatic ring in the mutant adopts the same orientation as the Y345 ring in wild type p58C (Figure 3B). We also determined the X-ray crystal structure of the Y347F variant, with a similarly low RMSD $(0.33 \AA$ ) relative to wild type p58C (Figure S8). DNA binding measurements using in vitro fluorescence anisotropy (Figure S1) under aerobic conditions demonstrate that the mutations do not significantly affect the binding of p58C to a range of DNA substrates. Since the structures and biochemical properties of the mutants are the same as WT p58C, but the electron/hole transfer properties of tyrosine and phenylalanine are different, these single-atom mutations provide a powerful means to investigate the importance of the CT pathway through $\mathrm{p} 58 \mathrm{C}$ and its effect on the DNAmediated redox switch in primase.

Anaerobic electrochemical characterization was performed on all three Y-F variants (Figure S9). Oxidation and reduction using bulk electrolysis, followed by redox cycling during CV scanning (Figure S10), were performed on an identical multiplex chip surface as for wild type p58C (Figure 3C). Though the general DNA-mediated electrochemical behavior of the mutants is the same as for the WT protein, it was observed that all three mutants are charge transfer-deficient compared to WT p58C. As a control that the phenomena we observed are not unique to Y-F substitution, we also assayed p58C Y345C, a somatic mutation discovered in a gastric tumor (40). Oxidation of each mutant produces a cathodic peak at potentials similar to wild type in CV scanning after electrolysis, with a much smaller signal height (Figure S9, S10) and a slightly positive shift in average cathodic peak potential (Figure S11), both of which suggest that the charge transfer pathway facilitating conversion from the native reduced, $[4 \mathrm{Fe} 4 \mathrm{~S}]^{2+}$ state to the oxidized, $[4 \mathrm{Fe} 4 \mathrm{~S}]^{3+}$ state is attenuated with mutation. Although perturbation of the CT pathway in p58C can be observed on DNA-modified electrodes, the rate-limiting step, tunneling of charge through the alkanethiol linker (31) 
appending the DNA to the gold surface, obscures a measurable difference in rate between wild type and mutant p58C redox switch pathways. Moreover, the scan rate dependence of the reductive peak potential is the same for WT p58C and p58C Y345L, a previously assayed tyrosine mutant, demonstrating that charge transfer through the 6-carbon alkanethiol linker is still rate limiting on this platform (Figure S12). Nonetheless, redox proficiency of WT and mutant p58C may be compared using charge transfer values over a fixed time in bulk electrolysis and CV.

Conversion of the reduced $[4 \mathrm{Fe} 4 \mathrm{~S}]^{2+} \mathrm{p} 58 \mathrm{C}$ to the oxidized $[4 \mathrm{Fe} 4 \mathrm{~S}]^{3+} \mathrm{p} 58 \mathrm{C}$ in bulk electrolysis, and subsequent conversion of the oxidized $[4 \mathrm{Fe} 4 \mathrm{~S}]^{3+} \mathrm{p} 58 \mathrm{C}$ to the reduced $[4 \mathrm{Fe} 4 \mathrm{~S}]^{2+} \mathrm{p} 58 \mathrm{C}$ in $\mathrm{CV}$, both require electron transfer through the protein, between bound duplex DNA and the [4Fe4S] cluster. If a pathway through conserved tyrosines mediates the redox switch, then less charge transfer in bulk electrolysis and CV should occur for the mutants. Diminished charge transfer through p58C during bulk electrolysis necessarily results in less oxidized mutant p58C being tightly bound to the DNA before CV scanning. This alone could produce the smaller CV signals observed. These signals, however, could also be diminished by the perturbed pathway impeding cluster oxidation in bulk electrolysis as well as reduction in $\mathrm{CV}$. To assess whether charge transfer deficiency is additive for the mutants over both electrolysis and CV, we compare the percent of initial electrolysis charge observed in the $\mathrm{CV}$ signal for WT and mutant $\mathrm{p} 58 \mathrm{C}$. Wild type $\mathrm{p} 58 \mathrm{C}$ recovers an average $63 \pm 4 \%$ of electrolysis charge in the $\mathrm{CV}$ peak, whereas the mutants recover an average of $24 \pm 11 \%$ (Y345C), 19 $\pm 10 \%$ (Y309F), 9 $\pm 4 \%$ (Y347F), and $3 \pm 2 \%$ (Y345F) of this charge under the same conditions (Figure 3D). The larger recovery percentage measured for $\mathrm{p} 58 \mathrm{C}$ Y345C may be due to transiently formed cysteine-thiyl radicals participating in a CT pathway through the protein with neighboring tyrosine residues $(41,42)$, partially retaining redox switching capability. These attenuations are on the order of magnitude expected from the positive shift in cathodic peak potential (2). The p58C Y345L mutant was, additionally, electrochemically assayed in the presence of both DNA and ATP. A reversible signal was observed, as with WT p58C, though the mutant displayed decreased charge transfer relative to WT. The mutants of p58C are thus CT-deficient, demonstrating that all three conserved tyrosine residues aid in shuttling charge between the $[4 \mathrm{Fe} 4 \mathrm{~S}]$ cluster and bound DNA.

\section{Redox Switch Required for Initiation but not Elongation}

In order to investigate the connection between the DNA-dependent redox switch in $\mathrm{p} 58 \mathrm{C}$ and priming activity, we assayed in vitro initiation and elongation activity of the full-length primase heterodimer and variants containing p58Y345F and p58Y345C mutations (Figure 4A, 4B). Anaerobic nucleotide incorporation assays were performed to test primase activity, measuring incorporation of ${ }^{-}{ }^{-32} \mathrm{P}$ labeled ATP on ssDNA for initiation and 2'-OMe RNAprimed DNA for elongation. Anaerobic conditions for these assays are necessary when measuring the effect of the redox switch on priming because atmospheric oxygen can oxidize the cluster when the protein is not bound to DNA. In the absence of oxygen, the switch mediated by a pathway of conserved tyrosine residues is thus the sole means through which to convert the enzyme from its native $[4 \mathrm{Fe} 4 \mathrm{~S}]^{2+}$ state to its tightly bound, CT-active $[4 \mathrm{Fe} 4 \mathrm{~S}]^{3+}$ state. We additionally note that in our assays, primase cannot truncate its products 
by handing them off to pol $\alpha$; instead, we observe a mixture of short primers and fully elongated 'primer-multimer' length products (Figure 4A, 4B, 5A, 5B) $(43,44)$.

To characterize initiation, we used a 50-nt ssDNA substrate (Table S1) containing exactly one complementary base for the radiolabeled nucleotide triphosphate, $\mathrm{a}^{-32} \mathrm{P}$ ATP. We found that WT primase has much higher overall initiation activity than both mutants tested, including the single-atom $\mathrm{p} 48 / \mathrm{p} 58 \mathrm{Y} 345 \mathrm{~F}$ variant (Figure 4A, 4B). CT-deficient primase mutants are significantly less active on ssDNA, synthesizing only $15-35 \%$ of the WT initiation products over multiple trials. Compared to WT primase, a larger portion of the products synthesized by the mutants is $<10$ nucleotides in length, suggesting that the ratedetermining initiation step in product synthesis is inhibited for mutants deficient in the redox switch. The significant difference in initiation activity for the WT and CT-deficient mutant primase enzymes suggests that a redox switch changing the oxidation state of the [4Fe4S] cluster in $\mathrm{p} 58 \mathrm{C}$ is crucial for the reaction to begin primer synthesis. Additionally, the difference in activity on ssDNA caused by a very subtle mutation in the CT pathway suggests that charge migration from bound DNA to the [4Fe4S] cofactor, through the insulating protein matrix of $\mathrm{p} 58 \mathrm{C}$, plays a significant role in mediating the rate-determining primase activation step on genomic template DNA, prior to the presence of duplex RNA/ DNA.

We next tested the effect of a perturbation in the CT pathway through $\mathrm{p} 58 \mathrm{C}$ on primase elongation. Primase can perform de novo primer synthesis on ssDNA, as well as elongation of an exogenous RNA primer on a duplex RNA/DNA substrate, in vitro $(9,16,45)$. The enzyme binds ssDNA more tightly than duplex segments (12), and this substrate preference leads to a mixture of products from both elongation of the exogenous primer and initiation on the ssDNA segment of the primed substrate. We designed a primed substrate for anaerobic elongation assays with WT and CT-deficient primase (Table S1); a 31-nt 2'-OMe RNA/DNA primer was annealed to a 60-nt DNA complement strand so that the primed substrate would contain a 31-nt RNA/DNA duplex sequence and a 29-nt 5'-ssDNA overhang. As expected, we observe a mixture of de novo initiation and primer elongation on these substrates with WT and mutant primase. We find that WT primase synthesizes more short, primer-length products through initiation on the ssDNA overhang and more truncated exogenous primers (Figure S14), slightly larger than 30-nt in length, while the CT-deficient mutant primase enzymes fully elongate the primer to 60-nt (Figure S15).

To examine the effect of additional copies of primase on the proportion of truncated versus fully elongated products formed, we repeated the experiment over a range of enzyme concentrations (200-800 nM). We had previously documented redox signaling using DNA CT between DNA repair proteins with [4Fe4S] clusters by atomic force microscopy $(3,4,6)$, even using repair protein partners from different organisms. Hence, we hypothesized here that redox signaling between primases through DNA CT could lead to the product truncation we observe. Since DNA CT can occur through RNA/DNA duplexes $(46,47)$, a redoxproficient partner for primase in vitro i.e. another primase molecule), provides a means for the enzyme to change redox state, thus truncate synthesis and hand off the primer-template. Within the cell, the partner for primase handoff would presumably be DNA polymerase $a$, which also contains a $[4 \mathrm{Fe} 4 \mathrm{~S}]$ cluster, rather than a second copy of primase. For these 
elongation assays, the products isolated were all at least $20 \mathrm{bp}$ long, which is easily large enough for two copies of primase to bind simultaneously on the duplex, based on modeling from structural data $(11,22,26,48)$, and be coupled into the duplex segment electronically. Quantification of products reveals that CT-proficient WT primase truncates products to a greater degree than the mutants, but the differences are small, especially between the WT and Y345F variants (Figure S15). This effect is not as striking as the difference seen between WT and mutant primase initiation activity, but the assay does underscore that $\mathrm{CT}$ proficiency is not critical to nucleotide polymerization in primase. Fully elongated, 60-nt products are synthesized by WT and mutant primase (Figure S16) to the same degree, within the margin of error.

\section{DNA Charge Transport Regulates Truncation and Handoff}

We next examined whether primase product truncation could be gated by DNA CT through the growing product duplex. This experiment provides a means to model substrate handoff by primase to pol $a$; the product duplex can mediate $\mathrm{CT}$ for the redox switch in protein binding and enable primer handoff, in this case between primase molecules (Figure 5C). We designed and prepared an exogenously primed substrate nearly identical to the substrate used in the WT/mutant comparison assay; the only difference was a single cytosine base engineered into the 5'-ssDNA overhang. The new elongation substrate (Table S1), under conditions promoting synthesis of a primer containing a destabilizing $\mathrm{C}: \mathrm{C}$ mismatch, should abrogate the CT signaling pathway through the RNA/DNA duplex and thus inhibit truncation of products by primase if DNA CT mediates the handoff. As anticipated, we observe that WT primase truncates significantly more products (Figure 5A, 5B) when the synthesized primer is well-matched than when the primer contains a single-base mismatch. This effect persists in anaerobic well-matched and mismatched primer elongation assays over a course of 30 to 120 minutes; we observe this effect over all concentrations of primase assayed (200 nM-800 nM) (Figure 5B, Figure S17). The striking difference in average percentage of truncated products (29-39\% with a well-matched primer, $9-12 \%$ with a mismatched primer at $\mathrm{t}=60$ minutes) demonstrates that primase uses DNA CT as a means to modulate DNA binding through changing the redox state of its $[4 \mathrm{Fe} 4 \mathrm{~S}]$ cluster.

\section{Implications for Primase Function in Replication}

Our initiation and elongation assays together suggest that DNA primase initiation and product truncation are both dependent on a redox switch changing the oxidation state of the [4Fe4S] cluster in $\mathrm{p} 58 \mathrm{C}$. The redox switch first activates primase to tightly bind DNA, initiating primer synthesis. DNA CT through the nascent RNA/DNA primer then mediates primase truncation. On the basis of the available structural and biochemical data (9$12,16,22-25,45$ ), we propose a model for priming that incorporates this redox switch (Figure 6). As DNA primase elongates the RNA primer to 8-12 nt length, a second [4Fe4S] enzyme, DNA polymerase a, comes into contact with the exposed nascent RNA/DNA helix (24) and associates with the primer-template so that its cluster is able to serve as a redox donor/ acceptor through primed DNA. A DNA-mediated redox event can then occur, promoting p58C dissociation from the duplex and pol a binding. Since most polymerases bind to their duplex DNA substrates with modest affinity, as we show is the case for primase, pol $a$ is 
unlikely to effectively take the primed substrate from primase. DNA-mediated signaling, which modulates polymerase binding affinity through a change in the redox state of the [4Fe4S] cluster, would thus provide the key driver for efficient primer handoff.

We propose that DNA-mediated CT drives signaling between the [4Fe4S] cluster cofactors in DNA primase and DNA polymerase $a$, facilitating rapid handoff of the RNA/DNA primer. Synthesis of a short primer to initiate replication must occur repeatedly on the lagging strand of the replication fork. DNA CT occurs on a timescale $(49,50)$ that could plausibly mediate this handoff; electron hopping through the protein matrix conversely occurs approximately 6 orders of magnitude more slowly $(37,38)$ and would not likely be the sole mediator of primase/polymerase a redox signaling between $[4 \mathrm{Fe} 4 \mathrm{~S}]$ centers. A major and likely rate-limiting conformational change for DNA polymerase a binding to DNA has been modeled on a timescale of 100-150 ns using molecular dynamics (24). DNA-mediated redox signaling between primase and pol a to promote primase dissociation and primertemplate transfer is thus a feasible redox mechanism for the proposed critical step for the primase-to-polymerase a transfer of the primer-template.

Our results support the proposal that the $[4 \mathrm{Fe} 4 \mathrm{~S}]$ cluster in p58C serves as a redox switch governing binding, and therefore initiation and primer length counting, in the first step of replication. We show that oxidation of the $[4 \mathrm{Fe} 4 \mathrm{~S}]^{2+}$ cluster in human DNA primase to the $[4 \mathrm{Fe} 4 \mathrm{~S}]^{3+}$ state facilitates DNA binding by the p58C domain. We demonstrate an electrochemically controlled redox signal for p58C on DNA, dependent on the effective concentration of $\mathrm{p} 58 \mathrm{C}$ at the DNA/solution interface, establishing a reversible redox switch. Conserved tyrosine residues in p58C on a pathway between the cluster and DNA mediate the redox reaction, affecting the $[4 \mathrm{Fe} 4 \mathrm{~S}]$ cluster oxidation state and, consequently, DNA association of p58C. Moreover, primase initiation and termination activity, but notably not elongation activity or DNA binding, are compromised in these CT-deficient tyrosine mutants. The $\mathrm{p} 58 \mathrm{C}$ domain has been proposed to contact ssDNA in the rate-determining primer initiation step $(12,15,16)$, and to play a role in the ability of the enzyme to count the length of the primer and signal for the arrest of further synthesis coupled with hand-off of the initial primed substrate to pol a (13).

The recent discovery of [4Fe4S] cluster cofactors in each of the B-family replicationassociated polymerases $\alpha, \varepsilon, \delta$, and $\zeta$ (17) is intriguing; combined with our results, this discovery suggests that redox reactions could be driving the DNA-binding switches generally necessary for polymerase handoffs. Moreover, studies similar to the work of Liu and Huang (51) investigating primase [4Fe4S] cluster sensitivity to oxidative stress may further illuminate how this chemistry relates to eukaryotic replication activity in different cellular redox environments. Could the redox switch for primase binding to DNA be part of a larger, DNA-mediated electron transfer relay coordinating the association, transfer, and dissociation steps of replication? Our results illustrate a chemical role for the [4Fe4S] cluster as a DNA-binding redox switch and point towards a new mechanism for coordinating activity within the dynamic replication fork. 


\section{Materials and Methods}

\section{Protein Expression and Purification}

Recombinant WT and mutant p58C were expressed and purified as previously described (11). For crystallization of the proteins, an extra affinity purification step was added before size exclusion chromatography. Both WT and mutant p58C were buffer exchanged into 20 mM HEPES (pH 7.2), $2 \mathrm{mM}$ DTT and $200 \mathrm{mM} \mathrm{NaCl}$. Each protein sample was then loaded onto a HiTrap ${ }^{\circledR}$ Heparin column and eluted with a gradient of 20 mM HEPES (pH 7.2), 2 $\mathrm{mM}$ DTT and $1 \mathrm{M} \mathrm{NaCl}$. To express primase, full-length p48 and p58 in the PBG100 and multiple cloning site 2 of the pETDuet vectors, respectively, were cotransformed into BL21 (RIL) D3 E. coli. The culture was grown in Terrific Broth at $37^{\circ} \mathrm{C}$ until it reached an O.D. of $0.5-0.8$, at which point the growth was transferred to an $18^{\circ} \mathrm{C}$ incubator. This was allowed to continue growing until it reached an OD of 1-1.5, at which point protein expression was induced with $0.5 \mathrm{mM}$ IPTG. The cells were harvested after expressing at $18^{\circ}$ $\mathrm{C}$ for 20 hours. To purify primase, cells were lysed using a sonicator and spun at 50,000 rcf. Supernatant loaded onto a nickel column equilibrated in Buffer A (20 mM Tris, $300 \mathrm{mM}$ $\mathrm{NaCl}$, and $20 \mathrm{mM}$ imidazole ( $\mathrm{pH}$ 8.0). After washing with five column volumes of Buffer A, the primase was eluted with Buffer B $(20 \mathrm{mM}$ Tris, $300 \mathrm{mM} \mathrm{NaCl}$, and $300 \mathrm{mM}$ imidazole ( $\mathrm{pH}$ 8.0). $\mathrm{H} 3 \mathrm{C}$ protease was added to primase-containing fractions, and these were dialyzed in to Buffer A at $4^{\circ} \mathrm{C}$ overnight. Primase was separated from the cleaved 6xHis tag (and uncleaved protein) by repassing over the nickel column. This sample was further purified by carefully diluting to $150 \mathrm{mM} \mathrm{NaCl}$, loading onto a HiTrap® Heparin column, and eluting with a gradient of $20 \mathrm{mM}$ HEPES (pH 7.2), $3 \%$ glycerol, and $1 \mathrm{M} \mathrm{NaCl}$. This was followed by size exclusion chromatography with a Superdex S200 column from GE Healthcare. Primase was eluted into a final storage buffer containing $20 \mathrm{mM}$ HEPES, $150 \mathrm{mM} \mathrm{NaCl}, 3 \%$ glycerol, $\mathrm{pH}$ 7.2.

\section{Site Directed Mutagenesis}

The Y309F, Y345F, and Y347F p58C mutants were created using a Q5 site directed mutagenesis kit from New England Biolabs. The following primers were supplied by Sigma Genosys to generate the mutant DNA plasmids. For Y309F, the forward primer was 5'CCGAATGCAGTTTGGCCTATTTC-3' and reverse primers was 5'CCTCCATGACGAAGATGG-3'. For Y345F, the forward primer was 5'TGATAAAGGTTTCTCTTACAACATCC-3' and reverse primers was 5'AACTTGTCTGGATCCATC-3'. For Y347F, the forward primer was 5'AGGTTACTCTTTCAACATCCGTC-3' and reverse primers was 5'TTATCAAACTTGTCTGGATCC-3'.

\section{Oligonucleotide preparation}

All standard or modified phosphoramidites and DNA synthesis reagents were purchased from Glen Research. Unmodified DNA and 2'-OMe RNA substrates used in electrochemical experiments or primase activity assays were purchased from Integrated DNA Technologies, Inc. DNA sequences for electrochemistry and primase activity assays are shown in Table S1. Thiol-modified DNA strands for electrochemistry were made on an Applied Biosystems 3400 DNA synthesizer, with a C6 S-S phosphoramidite incorporated at the 5'-terminus. 
Single-stranded DNA was purified using standard procedures as described previously. (5)

High pressure liquid chromatography (HPLC) using a reverse-phase PLRP-S column (Agilent) was used, and oligonucleotide mass confirmed using MALDI-TOF Mass Spectrometry. Thiol-modified strands were reduced after the initial HPLC purification with $100 \mathrm{mM}$ dithiothreitol (Sigma) for $2-3 \mathrm{~h}$ in $50 \mathrm{mM}$ Tris-HCl, pH 8.4, $50 \mathrm{mM} \mathrm{NaCl}$. Reduced thiol-modified DNA was purified by size exclusion chromatography (Nap5 Sephadex G-25, GE Healthcare) and subsequent reverse-phase HPLC. Single-stranded oligonucleotides were then desalted using ethanol precipitation and stored in low salt buffer (5 mM Phosphate, $\mathrm{pH}$ 7.0, $50 \mathrm{mM} \mathrm{NaCl}$ ). Duplex DNA for electrochemistry and duplex 2'-OMe RNA/DNA was prepared by quantification of the complementary single-stranded oligonucleotides by UVVisible spectroscopy, followed by annealing at $90{ }^{\circ} \mathrm{C}$. A mixture of equimolar complementary single-stranded DNA/2'-OMe RNA $(50 \mu \mathrm{M})$ was prepared in low salt buffer. Thiol-modified duplex DNA substrates were then deoxygenated by bubbling argon gas through the solution for $90 \mathrm{~s}$. Duplex DNA was annealed on a thermocycler (Beckman Instruments) by initial heating to $90{ }^{\circ} \mathrm{C}$, followed by slow cooling to $4{ }^{\circ} \mathrm{C}$ over 90 minutes. DNA was quantified using absorbance at $260 \mathrm{~nm}$, with extinction coefficients at $260 \mathrm{~nm}$ for DNA or 2'-OMe RNA obtained using Integrated DNA Technologies online OligoAnalyzer tool. Single-stranded DNA substrates were quantified using UV-Visible spectroscopy and stored in low salt buffer at a stock concentration for activity assays.

\section{Multiplexed Chip Fabrication}

Multiplexed electrode platforms were prepared using standard photolithography techniques, adapted from established protocols $(5,31,32)$. Nine 1 in. by 1 in. chips were patterned on 525 $\mu \mathrm{m}$ thick silicon wafers (SiliconQuest). A thermal oxide layer roughly $4000 \AA$ thick was grown on the silicon wafers using a Tytan tube furnace (Tystar). S1813 photoresist $(2 \mu \mathrm{m}$ layer) was deposited onto the wafers for patterning of the chips before metal deposition. Electron beam evaporation (CHA Industries) was then used to deposit a $3 \mathrm{~nm}$ titanium adhesion layer followed by a 100nm gold layer, without breaking vacuum between depositions. Metal lift-off using Remover PG (MicroChem) was performed overnight (10$12 \mathrm{~h}$ ) at room temperature. Wafers were subsequently dried with a nitrogen gun and dehydrated at $140{ }^{\circ} \mathrm{C}$ for 10 minutes. A $3 \mu$ m layer of insulating SU-8 photoresist was deposited and patterned onto the wafer as described previously, $(5,31,32)$ with connective wires between contact pads on the edges of the chips and working electrodes in the center were covered but the contact pads and working electrodes left exposed. This ensured a fixed working electrode surface area of $2 \mathrm{~mm}^{2}$. SU-8 photoresist was cured $\left(150{ }^{\circ} \mathrm{C}, 15\right.$ minutes) and wafers cleaved into individual chips using a Dynatex Scriber/Breaker.

\section{DNA Modified Electrode Assembly/Preparation}

Multiplexed chips were cleaned using sonication in acetone and isopropyl alcohol as described previously (5). Chips were then dried using argon gas and ozone-cleaned for 1520 minutes at $20 \mathrm{~mW}$ using a Uvo brand ozone cleaner. Clean chips were assembled onto polycarbonate holders with acrylic clamp and Buna-N rubber gasket according to previous protocols, with four quadrants in the chip separated by fastened gasket and clamp (5). Duplex DNA substrates, with a thiol modifier at the 5'- end, $(25 \mu \mathrm{M})$ were deposited in a 20 uL volume onto each quadrant of the multiplex chip. Substrates incubated for 18-24 hours 
on the gold surface to allow formation of self-assembled DNA monolayer. DNA monolayers were washed with phosphate buffer ( $5 \mathrm{mM}$ phosphate, $\mathrm{pH} 7.0,50 \mathrm{mM} \mathrm{NaCl}, 5 \%$ glycerol) and subsequently backfilled with $1 \mathrm{mM} 6$-mercaptohexanol (Sigma) in phosphate buffer for 45 minutes. Monolayers are then washed 10 times per quadrant with phosphate buffer and twice per quadrant with TBP buffer ( $5 \mathrm{mM}$ phosphate, $\mathrm{pH} 7.0,50 \mathrm{mM} \mathrm{NaCl}, 4 \mathrm{mM} \mathrm{MgCl}{ }^{2} 4$ $\mathrm{mM}$ spermidine) to aid in formation of a monolayer with termini accessible for $\mathrm{p} 58 \mathrm{C}$ binding. Assembled chips were transported into an anaerobic glove bag chamber (Coy Products) and washed 5 times per quadrant with p58C storage buffer ( $20 \mathrm{mM}$ Tris- $\mathrm{HCl}, \mathrm{pH}$ $7.2,75 \mathrm{mM} \mathrm{NaCl}$ ), which was previously deoxygenated by argon bubbling (approx. 1 hour per $\mathrm{mL}$ of buffer solution) and allowed to incubate at least 1-2 days in the chamber prior to the experiment. Initial cyclic voltammetry scans of the monolayers in p58C storage buffer were performed to ensure monolayer formation on each electrode. All washes were performed with $20 \mu \mathrm{L}$ buffer volumes on each quadrant. Before scanning, a $200 \mu \mathrm{L}$ volume was deposited over the chip surface, a bulk solution well for completion of a three-electrode circuit with an external reference and counter electrode.

\section{Mutant Selection and Design}

Mutations in the $\mathrm{p} 58 \mathrm{C}$ domain of human DNA primase were designed based on previously determined structural data (11) and bioinformatics (12) compiled for conserved residues in this domain. PYMOL software was used to model the mutations in a $1.7 \AA$ resolution structure of human p58C (11) (PDB 3L9Q). Mutagenesis and measurement tools were used to model possible point mutations and approximate distances between residues/cofactors. The COSMIC database (40) was used to search for somatic mutations of the primase large subunit (PRIM2 gene) in cancer. The point mutation Y345C was found and selected for charge transfer and activity assays.

\section{Circular Dichroism}

The WT and mutants of p58C were concentrated to $2 \mathrm{mg} / \mathrm{mL}$ and buffer exchanged into 10 $\mathrm{mM}$ potassium phosphate ( $\mathrm{pH}$ 7.2). The far-UV CD spectrum over the range 190-260 nm was acquired at room temperature using a Jasco J-810 spectrophotometer. Each spectrum is the average of three scans acquired with a scanning rate of $0.5 \mathrm{~nm} / \mathrm{s}$.

\section{Fluorescence anisotropy}

The binding of DNA to wild-type and mutant $\mathrm{p} 58 \mathrm{C}$ and primase was measured by monitoring the change (increase) in fluorescence anisotropy as protein was added to a solution containing 5'-FITC labeled DNA (see Table S1 for substrates). The p58C DNA substrate was annealed using a buffer containing $20 \mathrm{mM}$ MES (pH 6.5) and $75 \mathrm{mM} \mathrm{NaCl}$. In each case, an increasing concentration of protein was added to a solution containing DNA substrate at a concentration of $50 \mathrm{nM}$ (p58C) or $20 \mathrm{nM}$ (primase). Polarized fluorescence intensities were measured using excitation and emission wavelengths of $485 \mathrm{~nm}$ and $520 \mathrm{~nm}$ using a SpectraMax M5 microplate reader (Molecular Devices). 


\section{X-ray crystallography}

Crystals of Y347F p58C were grown by hanging drop vapor diffusion at $21^{\circ} \mathrm{C}$ from a drop composed of equal volumes of $75 \mathrm{mg} / \mathrm{ml}$ protein in $20 \mathrm{mM}$ TRIS (pH 7.2) and $75 \mathrm{mM} \mathrm{NaCl}$ and reservoir solution containing $100 \mathrm{mM}$ Tris (pH 8.5), $300 \mathrm{mM} \mathrm{Li}_{2} \mathrm{SO}^{4}$ and 20\% PEG 3350. Crystals of Y345F p58C were grown in $20 \mathrm{mM}$ MES (pH 6.5) and $50 \mathrm{mM} \mathrm{NaCl}$ and reservoir solution containing $100 \mathrm{mM}$ Tris (pH 8.5) $150 \mathrm{mM} \mathrm{Li}_{2} \mathrm{SO}_{4}$ and 18\% PEG 3350. Crystal growth was stimulated by streak seeding with WT. Prior to data collection, crystals were soaked in mother liquor containing $20 \%$ glycerol and flash frozen in liquid nitrogen. X-ray data were collected at Sector 21 (Life Sciences Collaborative Access Team) of the Advanced Photon Source at Argonne National Laboratory. All data were processed by HKL2000. The Y347F crystals belong to the P3 space group and were twinned. The Y345F crystals were not twinned and belonged to the $\mathrm{C} 2$ space group. Prior to phasing, the twinned data set was de-twinned using the Detwin program of the CCP4 program suite (Collaborative Computational Project, 1994) by applying the twin law, h,-h-k,-l. Phasing of the diffraction data was done by molecular replacement using PHASER and PDB entry $3 \mathrm{~L} 9 \mathrm{Q}$ as the search model. Manual model building for the structure was performed using Coot model building software, and waters were placed with the Coot routine, Find Waters. The final model was obtained by iterative cycles of model building in Coot and structure refinement using Refmac5 in the CCP4 suite of programs. The final model of Y347F was a dimer of dimers with four Y347F p58C subunits in the asymmetric unit. The final model of $\mathrm{Y} 345 \mathrm{~F}$ was a dimer with two $\mathrm{Y} 345 \mathrm{~F}$ subunits in the asymmetric unit. All protein figures were prepared with Chimera. Data collection and refinement statistics are given in Table S2.

\section{Sample Preparation for Electrochemistry}

Wild type and mutant $\mathrm{p} 58 \mathrm{C}$ samples were stored prior to experiments in $\mathrm{p} 58 \mathrm{C}$ storage buffer. Concentrations of [4Fe4S] cluster-containing p58C or mutants were measured using UV-Visible spectroscopy, by absorbance of the [4Fe4S] cluster at $410 \mathrm{~nm}$ (extinction coefficient $\left.=17000 \mathrm{M}^{-1} \mathrm{~cm}^{-1}\right)(52)$. Aliquots of stock samples $(45-90 \mu \mathrm{L})$ were deoxygenated using argon bubbling for 4-5 minutes. Samples were then transferred into the anaerobic chamber. Before deposition onto the gold electrode surface, $\mathrm{p} 58 \mathrm{C} /$ mutant samples were diluted to a molar concentration of $16 \mu \mathrm{M}[4 \mathrm{Fe} 4 \mathrm{~S}]$ p58C variant with previously deoxygenated $\mathrm{p} 58 \mathrm{C}$ storage buffer. Samples were deposited onto multiplex chip quadrants in $20 \mu \mathrm{L}$ volumes initially, with the remaining sample deposited in a well of bulk solution above the chip surface.

\section{Wild Type/Mutant p58C Electrochemistry}

All electrochemistry was performed using a CHI620D potentiostat and 16-channel multiplexer (CH Instruments), in an anaerobic glove chamber. Multiplex gold electrodes were part of a three electrode system with an external $\mathrm{Ag} / \mathrm{AgCl}$ reference electrode (Bioanalytical Systems) and platinum counter electrode. Cyclic voltammetry scans were performed at $100 \mathrm{mV} / \mathrm{s}$ scan rates, over a potential range of $+0.412 \mathrm{~V}$ to $-0.288 \mathrm{~V}$ vs. NHE. Bulk electrolysis on DNA was performed at an applied potential of $+0.412 \mathrm{~V}$ vs. NHE for all electrochemical oxidation reactions and $-0.188 \mathrm{~V}$ vs. NHE for all electrochemical reduction reactions. The oxidizing potential was applied for 8.33 minutes for single oxidation 
reactions on a surface, and 5.83 minutes or 6.67 minutes for the iterative oxidation cycles of p58C variants. The reducing potential was applied for 8.33 minutes in all electrochemical reduction reactions. All bulk electrolysis and cyclic voltammetry was performed in previously deoxygenated p58C storage buffer ( $20 \mathrm{mM}$ Tris, $\mathrm{pH} 7.2,75 \mathrm{mM} \mathrm{NaCl})$. Charge transfer (nC) in the cathodic peak of oxidized samples' CV scans was assessed using the area under the current wave of the reduction signal. All p58C variants were compared over three trials of oxidation at $+0.412 \mathrm{~V}$ vs. NHE (two oxidation reactions after $500 \mathrm{~s}$ of applied potential, one reaction after $400 \mathrm{~s}$ of applied potential). The charge transfer in the bulk electrolysis curves was calculated as the area under the current curve plotted versus time for the bulk electrolysis reaction, as the current decays to a constant value. The percent recovery of bulk electrolysis charge in the CV peak after oxidation was averaged over three trials for each variant; error bars represent the standard deviation of the average fraction of charge recovered.

\section{Full-Length Wild Type/Mutant Primase Initiation and Elongation Assays}

All activity assays were performed in an anaerobic glove chamber (Coy Products) using previously deoxygenated buffer, protein, DNA substrates, and nucleotide triphosphates. All reagents were deoxygenated by argon gas bubbling after thawing from storage temperature immediately prior to assay. Buffer was deoxygenated by bubbling argon gas for several hours (approx. 1 hour per $\mathrm{mL}$ buffer) and subsequent incubation in the glove chamber atmosphere for at least 1-2 days prior to the assay. Initiation assays were performed using the 50-nt Initiation Substrate listed in Table S1. Elongation assays were performed with the Elongation Substrate in Table S1, in which a 2'-OMe RNA/DNA primer is annealed to a 60nt ssDNA complement strand. Initiation assays ( $18 \mu \mathrm{L}$ total volume) contained $250 \mathrm{nM}$ ssDNA Initiation Substrate, $1 \mu \mathrm{M}$ [a- ${ }^{32} \mathrm{P}$ ATP] (Perkin Elmer), $112 \mu \mathrm{M}$ [CTP] (Sigma), 188 $\mu \mathrm{M}$ [UTP] (Sigma), and $400 \mathrm{nM}$ primase or primase variant, in $50 \mathrm{mM}$ Tris-HCl, $\mathrm{pH} 8.0,3$ $\mathrm{mM} \mathrm{MgCl} 2$. Reactions were initiated by the addition of primase or primase variant enzyme and incubated anaerobically at $37^{\circ} \mathrm{C}$. Aliquots $(5.5 \mu \mathrm{L})$ were removed from the primase reactions after 5 minutes, 10 minutes, and 30 minutes of incubation for wild type/mutant comparison assays and after 30 minutes, 60 minutes, and 120 minutes for wild type primase well-matched and mismatched primer comparison assays. All samples were quenched by addition of an equal volume of 1\% SDS (Sigma), $25 \mathrm{mM}$ EDTA (Sigma) solution. Samples were then removed from the glove chamber after quenching and heat denatured at $70^{\circ} \mathrm{C}$. Products were then purified by size exclusion, using mini Quick Spin Oligo columns (Roche Diagnostics) for wild type/mutant comparison assays and Micro-Bio Spin ${ }^{\mathrm{TM}} \mathrm{P}-6$ columns (BioRad Laboratories) for wild type well-matched/mismatched primer comparison assays. Radioactivity counts for products were measured using a LS5000TD scintillation counter (Beckman Instruments). Products were dried in vacuo, resuspended in $2 \mu \mathrm{L}$ loading dye (Xylene cyanol, bromophenol blue), and further annealed for 1 minute at $90^{\circ} \mathrm{C}$ before gel separation. Primase/mutant comparison elongation assays were performed under identical conditions, in the presence of 500nM Well-Matched Elongation Substrate, 120 $\mu$ M CTP (Sigma), $180 \mu \mathrm{M}$ UTP (Sigma), and $1 \mu \mathrm{M} \mathrm{a}^{3}{ }^{32} \mathrm{P}$ ATP (Perkin Elmer). The primase/variant concentrations used in elongation assays were $200 \mathrm{nM}, 400 \mathrm{nM}, 600 \mathrm{nM}$, or $800 \mathrm{nM}$. Primase

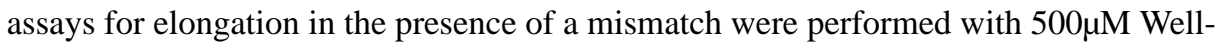

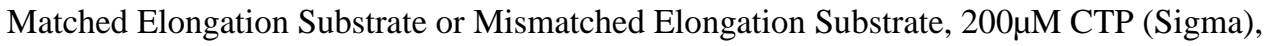


100 $\mu \mathrm{M}$ UTP (Sigma), and $1 \mu \mathrm{M} \mathrm{a-}{ }^{32} \mathrm{P}$ ATP (Perkin Elmer). Assays were performed anaerobically and quenched/purified in a manner identical to initiation assays.

\section{Primase Assay Product Separation/Analysis}

All primase/primase variant assay products were separated by denaturing polyacrylamide gel electrophoresis (20\% polyacrylamide). Separated products were visualized using phosphorimagery on a Typhoon FLA 9000 imager (GE Healthcare) and quantified using ImageQuant TL software. Products synthesized by different primase variants were directly compared using measured ${ }^{32} \mathrm{P}$ counts detected by software. Initiation and Elongation Substrates (Table S1) were designed to contain a single base complementary to the radiolabeled NTP, $a-{ }^{32} \mathrm{P}$ ATP. Quantification could thus have a basis 1:1 product: radioactivity ratio, as the sole purine NTP and would be the strongly preferred site of initiation and an optimal 5'- elongation site $(53,54)$. Product sizes were assigned by comparison with a 10/60 Oligo Length Standard (Integrated DNA Technologies). Singlestranded oligonucleotides in standard were labeled by incubation for 1 hour at $37^{\circ} \mathrm{C}$ with $\gamma^{-32} \mathrm{P}$ ATP (Perkin Elmer) and T4 polynucleotide kinase enzyme (Roche Diagnostics). Labeled standard was purified using size exclusion chromatography with mini Quick Spin Oligo columns (Roche Diagnostics). All product quantifications were averaged over three trials for $\mathrm{p} 48 / \mathrm{p} 58 \mathrm{Y} 345 \mathrm{~F}$ and $\mathrm{p} 48 / \mathrm{p} 58 \mathrm{Y} 345 \mathrm{C}$ and six trials for $\mathrm{p} 48 / \mathrm{p} 58$. Error bars represent the standard deviation of average values obtained over these trials.

\section{Supplementary Material}

Refer to Web version on PubMed Central for supplementary material.

\section{References and Notes}

1. Grodick MA, Muren NB, Barton JK. DNA charge transport within the cell. Biochemistry. 2015; 54:962-973. [PubMed: 25606780]

2. Gorodetsky AA, Boal AK, Barton JK. Direct electrochemistry of endonuclease III in the presence and absence of DNA. J. Am. Chem. Soc. 2006; 128:12082-12083. [PubMed: 16967954]

3. Boal AK, Genereux JC, Sontz PA, Gralnick JA, Newman DK, Barton JK. Redox signaling between DNA repair proteins for efficient lesion detection. Proc. Natl. Acad. Sci. USA. 2009; 106:1523715242. [PubMed: 19720997]

4. Sontz PA, Mui TP, Fuss JO, Tainer JA, Barton JK. DNA charge transport as a first step in coordinating the detection of lesions by repair proteins. Proc. Natl. Acad. Sci. USA. 2012; 109:1856-1861. [PubMed: 22308447]

5. Pheeney CG, Arnold AR, Grodick MA, Barton JK. Multiplexed electrochemistry of DNA-bound metalloproteins. J. Am. Chem. Soc. 2013; 135:11869-11878. [PubMed: 23899026]

6. Grodick MA, Segal HM, Zwang TJ, Barton JK. DNA-mediated signaling by proteins with $4 \mathrm{Fe}-4 \mathrm{~S}$ clusters is necessary for genomic integrity. J. Am. Chem. Soc. 2014; 136:6470-6478. [PubMed: 24738733]

7. Rees DC, Howard JB. The interface between the biological and inorganic worlds: iron-sulfur metalloclusers. Science. 2003; 300:929-931. [PubMed: 12738849]

8. Rouault TA. Mammalian iron-sulphur proteins: novel insights into biogenesis and function. Nature Reviews Molecular Cell Biology. 2015; 16:45-55. [PubMed: 25425402]

9. Klinge S, Hirst J, Maman JD, Krude T, Pellegrini L. An iron-sulfur domain of the eukaryotic primase is essential for primer synthesis. Nat. Struct. Mol. Biol. 2007; 14:875-877. [PubMed: 17704817] 
10. Weiner BE, Huang H, Dattilo BM, Nilges MJ, Fanning E, Chazin WJ. An iron-sulfur cluster in the c-terminal domain of the p58 subunit of human DNA primase. J. Biol. Chem. 2007; 282:3344433451. [PubMed: 17893144]

11. Vaithiyalingam S, Warren EM, Eichman BF, Chazin WJ. Insights into eukaryotic priming from the structure and functional interactions of the $4 \mathrm{Fe}-4 \mathrm{~S}$ cluster domain of human DNA primase. Proc. Natl. Acad. Sci. USA. 2010; 107:13684-13689. [PubMed: 20643958]

12. Sauguet L, Klinge S, Perera RL, Maman JD, Pellegrini L. Shared active site architecture between the large subunit of eukaryotic primase and DNA photolyase. PloS One. 2010; 5:e10083. [PubMed: 20404922]

13. Agarkar VB, Babayeva ND, Pavlov YI, Tahirov TH. Crystal structure of the c-terminal domain of human DNA primase large subunit. Cell Cycle. 2011; 10:926-931. [PubMed: 21346410]

14. Baranovskiy AG, Zhang Y, Suwa Y, Babayeva ND, Gu J, Pavlov YI, Tahirov TH. Crystal structure of the human primase. J. Biol. Chem. 2015; 290:5635-5646. [PubMed: 25550159]

15. Kilkenny ML, De Piccoli G, Perera RL, Labib K, Pellegrini L. A conserved motif in the c-terminal tail of DNA polymerase a tethers primase to the eukaryotic replisome. J. Biol. Chem. 2012; 287:23740-23747. [PubMed: 22593576]

16. Kilkenny ML, Longo MA, Perera RL, Pellegrini L. Structures of human primase reveal design of nucleotide elongation site and mode of pol a tethering. Proc. Natl. Acad. Sci. USA. 2013; 110:15961-15966. [PubMed: 24043831]

17. Netz DJA, Stith CM, Stümpfig M, Köpf G, Vogel D, Genau HM, Stodola JL, Lill R, Burgers PMJ, Pierik AJ. Eukaryotic DNA polymerases require an iron-sulfur cluster for the formation of active complexes. Nature Chemical Biology. 2012; 8:125-132.

18. Frick DN, Richardson CC. DNA Primases. Annu. Rev. Biochem. 2001; 70:39-80. [PubMed: 11395402]

19. Kuchta RD, Stengel G. Mechanism and evolution of DNA primases. Biochimica et Biophysica Acta. 2010; 1804:1180-1189. [PubMed: 19540940]

20. Arezi B, Kuchta RD. Eukaryotic DNA primase. Trends in Biochemical Sciences. 2000; 25:572576. [PubMed: 11084371]

21. O'Donnell ME, Langston L, Stillman B. Principles and concepts of DNA replication in bacteria, archaea, and eukarya. Cold Spring Harbor Perspectives in Biology. 2013; 5:a010108. [PubMed: 23818497]

22. Baranovskiy AG, Babayeva ND, Zhang Y, Gu J, Suwa Y, Pavlov YI, Tahirov TH. Mechanism of Concerted RNA-DNA Primer Synthesis by the Human Primosome. J. Biol. Chem. 2016; 10 1074/ jbc.M116.717405.

23. Klinge S, Núnez-Ramírez R, Llorca O, Pellegrini L. 3D architecture of DNA Pol a reveals the functional core of multi-subunit replicative polymerases. EMBO J. 2009; 28:1978-1987. [PubMed: 19494830]

24. Perera RL, Torella R, Klinge S, Kilkenny ML, Maman JD, Pellegrini L. Mechanism for priming DNA synthesis by yeast DNA polymerase a. eLife. 2013; 2:e00482. [PubMed: 23599895]

25. Vaithiyalingam S, Arnett DR, Aggarwal A, Eichman BF, Fanning E, Chazin WJ. Insights into Eukaryotic Primer Synthesis from Structures of the p48 Subunit of Human DNA Primase. J. Mol. Biol. 2014; 426:558-569. [PubMed: 24239947]

26. Lue NF, Chan J, Wright WE, Hurwitz J. The Cdc13-Stn1-Ten1 complex stimulates pol a activity by promoting RNA priming and primase-to-polymerase switch. Nature Communications. 2014; 5:5762.

27. Georgescu RE, Schauer GD, Yao NY, Langston LD, Yurieva O, Zhang D, Finkelstein J, O’Donnell ME. Reconstitution of a eukaryotic replisome reveals suppression mechanisms that define leading/ lagging strand operation. eLife. 2015; 4:e04988. [PubMed: 25871847]

28. Zerbe LK, Kuchta RD. The p58 subunit of human DNA primase is important for primer initiation, elongation, and counting. Biochemistry. 2002; 41:4891-4900. [PubMed: 11939784]

29. Garg P, Burgers PMJ. DNA polymerases that propagate the eukaryotic DNA replication fork. Critical Reviews in Biochemistry and Molecular Biology. 2005; 40:115-128. [PubMed: 15814431]

30. Fuss J, Tsai C, Ishida J, Tainer J. Emerging critical roles of Fe-S clusters in DNA replication and repair. BBA. 2015; 1853:1253-1271. [PubMed: 25655665] 
31. Slinker JD, Muren NB, Gorodetsky AA, Barton JK. Multiplexed DNA-modified electrodes. J. Am. Chem. Soc. 2010; 132:2769-2774. [PubMed: 20131780]

32. Slinker JD, Muren NB, Renfrew SE, Barton JK. DNA charge transport over $34 \mathrm{~nm}$. Nat. Chem. 2011; 3:228-233. [PubMed: 21336329]

33. Boal AK, Yavin E, Lukianova OA, O'Shea VL, David SS, Barton JK. DNA-bound redox activity of DNA repair glycosylases containing [4Fe4S] clusters. Biochemistry. 2005; 44:8397-8407. [PubMed: 15938629]

34. Imlay JA. Iron-sulphur clusters and the problem with oxygen. Molecular Microbiology. 2006; 59:1073-1082. [PubMed: 16430685]

35. Mui TP, Fuss JO, Ishida JP, Tainer JA, Barton JK. ATP-Stimulated, DNA-Mediated Redox Signaling by XPD, a DNA Repair and Transcription Helicase. J. Am. Chem. Soc. 2011; 133:16378-16381. [PubMed: 21939244]

36. Winkler JR, Gray HB. Long-range electron tunneling. J. Am. Chem. Soc. 2014; 136:2930-2939. [PubMed: 24499470]

37. Gray HB, Winkler JR. Electron flow through metalloproteins. BBA. 2010; 1797:1563-1572. [PubMed: 20460102]

38. Shih C, Museth AK, Abrahamsson M, Blanco-Rodriguez AM, Di Bilio AJ, Sudhamsu J, Crane BR, Ronayne KL, Towrie M, Vlcek A Jr, Richards JH, Winkler JR, Gray HB. Tryptophanaccelerated electron flow through proteins. Science. 2008; 320:1760-1762. [PubMed: 18583608]

39. Plekan O, Feyer V, Richter R, Coreno M, Prince KC. Valence photoionization and photofragmentation of aromatic amino acids. Molecular Physics. 2008; 106:1143-1153.

40. Forbes SA, Bindal N, Bamford S, Cole C, Kok CY, Beare D, Jia M, Shepherd R, Leung K, Menzies A, Teague JW, Campbell PJ, Stratton MR, Futreal PA. COSMIC: mining complete cancer genomes in the Catalogue of Somatic Mutations in Cancer. Nucleic Acids Res. 2011; 39:D945D950. [PubMed: 20952405]

41. Stubbe J, Nocera DG, Yee CS, Chang MCY. Radical initiation in the class I ribonucleotide reductase: long-range proton-coupled electron transfer? Chem. Rev. 2003; 103:2167-2202. [PubMed: 12797828]

42. Stubbe J, van der Donk WA. Protein Radicals in Enzyme Catalysis. Chem. Rev. 1998; 98:705-762. [PubMed: 11848913]

43. Sheaff RJ, Kuchta RD, Ilsley D. Calf thymus DNA polymerase-a-primase: "communication" and primer template movement between the two active sites. Biochemistry. 1994; 33:2247-2254. [PubMed: 8117681]

44. Sheaff RJ, Kuchta RD. Misincorporation of nucleotides by calf thymus DNA primase and elongation of primers containing multiple noncognate nucleotides by DNA polymerase a. J. Biol. Chem. 1994; 269:19225-19231. [PubMed: 8034683]

45. Núnez-Ramírez R, Klinge S, Sauguet L, Melero R, Recuero-Checa MA, Kilkenny M, Perera RL, Garcia-Alvarez B, Hall RJ, Nogales E, Pellegrini L, Llorca O. Flexible tethering of primase and DNA Pol $a$ in the eukaryotic primosome. Nucleic Acids Res. 2011; 39:8187-8199. [PubMed: 21715379]

46. O'Neill MA, Barton JK. 2-Aminopurine: a probe of structural dynamics and charge transfer in DNA and DNA:RNA hybrids. J. Am. Chem. Soc. 2002; 124:13053-13066. [PubMed: 12405832]

47. Boon EM, Barton JK. DNA Electrochemistry as a probe of base-pair stacking in A-, B-, and Zform DNA. Bioconjugate Chem. 2003; 14:1140-1147.

48. Garcia-Diaz M, Bebenek K, Krahn JM, Pedersen LC, Kunkel TA. Role of the catalytic metal during polymerization by DNA polymerase lambda. DNA Repair. 2007; 6:1333-1340. [PubMed: 17475573]

49. O’Neill MA, Barton JK. DNA-Mediated Charge Transport Requires Conformational Motion of the DNA Bases: Elimination of Charge Transport in Rigid Glasses at 77 K. J. Am. Chem. Soc. 2004; 126:13234-13235. [PubMed: 15479072]

50. O’Neill MA, Becker H-C, Wan C, Barton JK, Zewail AH. Ultrafast Dynamics in DNA-Mediated Electron Transfer: Base Gating and the Role of Temperature. Angew. Chem. Int. Ed. 2003; 42:5896-5900. 
51. Liu L, Huang M. Essential role of the iron-sulfur cluster binding domain of the primase regulatory subunit Pri2 in DNA replication initiation. Protein Cell. 2015; 6:194-210. [PubMed: 25645023]

52. Cunningham RP, Asahara H, Bank JF, Scholes CP, Salerno JC, Surerus K, Munck E, McCracken J, Peisach J, Emptage MH. Endonuclease III is an iron-sulfur protein. Biochemistry. 1989; 28:44504455. [PubMed: 2548577]

53. Holmes AM, Cheriathundam E, Bollum FJ, Chang LM. Initiation of DNA synthesis by the calf thymus DNA polymerase-primase complex. J. Biol. Chem. 1985; 260:10840-10846. [PubMed: 3161883]

54. Suzuki M, Savoysky E, Izuta S, Tatebe M, Okajima T, Yoshida S. RNA priming coupled with DNA synthesis on natural template by calf thymus DNA polymerase alpha-primase. Biochemistry. 1993; 32:12782-12792. [PubMed: 7504526]

55. Laviron E. General expression of the linear potential sweep voltammagram in the case of diffusionless electrochemical systems. J. Electroanal. Chem. 1979; 101:19-28. 
A

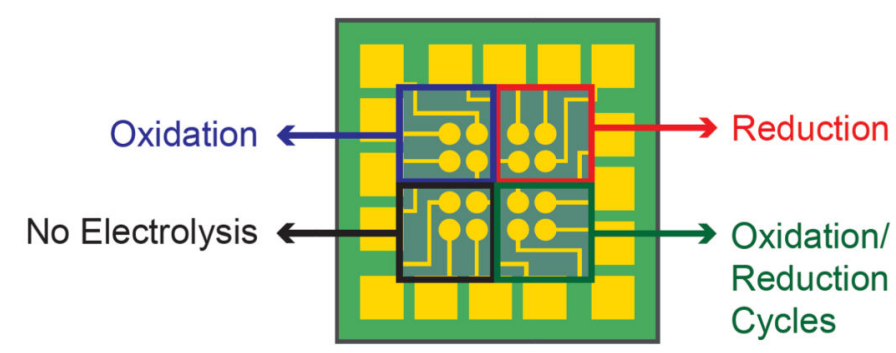

B

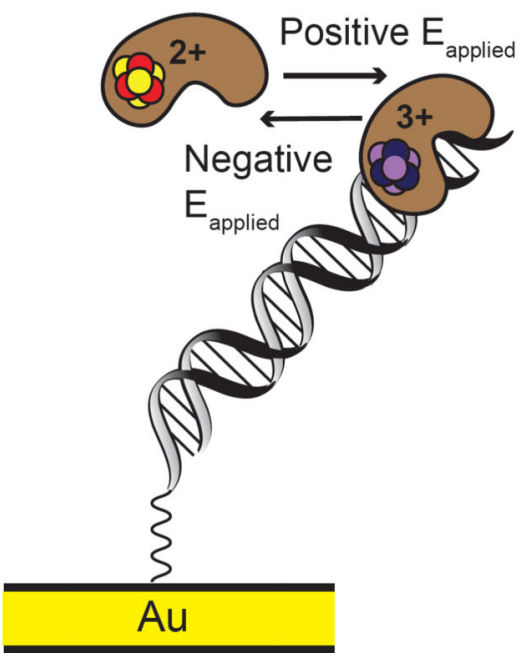

C

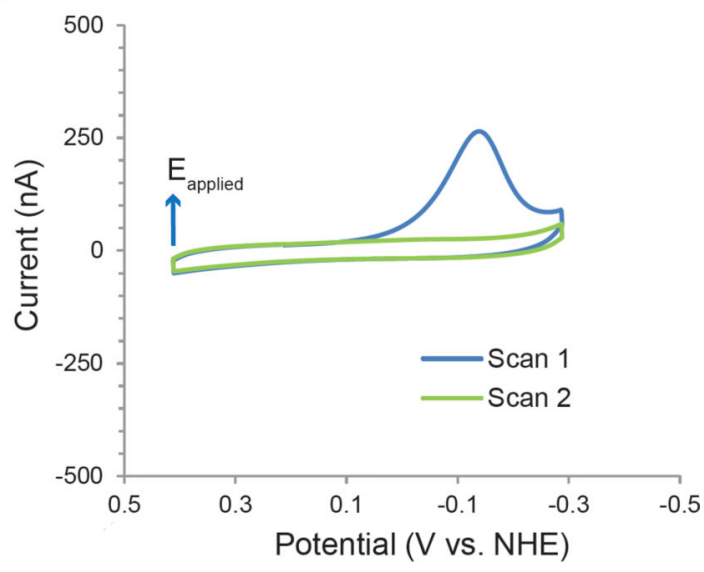

D

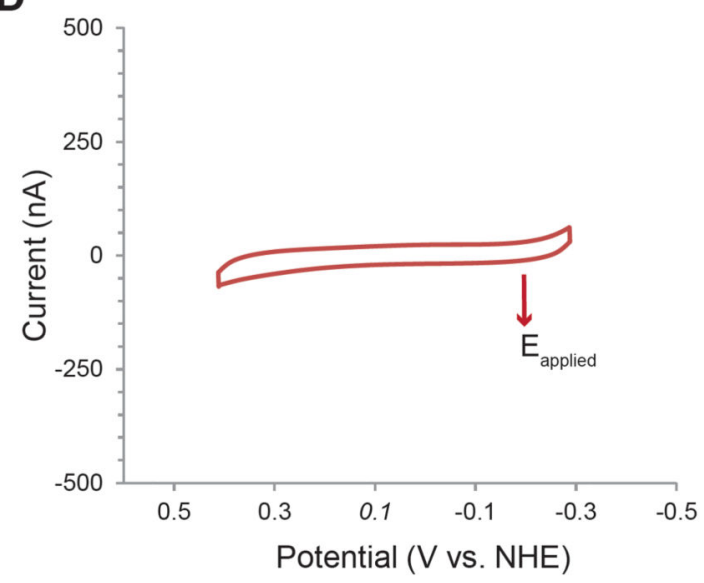

Figure 1. Oxidized $[4 \mathrm{Fe} 4 \mathrm{~S}]^{3+}$ and reduced $[4 \mathrm{Fe} 4 \mathrm{~S}]^{2+}$ p58C display different behavior on DNAmodified electrodes

A) Multiplex chip with 16 DNA-modified Au electrodes (circles, center.) This platform facilitates direct comparison of oxidized, reduced, unaltered, and iteratively oxidized samples, on four separate quadrants of a single surface. B) The cartoon depicts the effects of electrochemical oxidation and reduction on p58C DNA binding and redox activity. $\mathrm{C}$ ) $\mathrm{CV}$ of electrochemically oxidized p58C. After electrochemical conversion $\left(E_{\text {applied }}=412 \mathrm{mV}\right.$ vs. $\mathrm{NHE}$ ) of the sample at the electrode/solution interface to the $[4 \mathrm{Fe} 4 \mathrm{~S}]^{3+}$ state, $\mathrm{CV}$ scans display a large cathodic peak only in the initial scan to negative, reducing potentials. D) CV of electrochemically reduced $\mathrm{p} 58 \mathrm{C}$. After electrochemical conversion $\left(\mathrm{E}_{\text {applied }}=-188 \mathrm{mV}\right.$ vs. NHE) of the sample to the $[4 \mathrm{Fe} 4 \mathrm{~S}]^{2+}$ state, $\mathrm{CV}$ scans show no electrochemical signal on DNA. Electrochemistry was performed on $16 \mu \mathrm{M}$ p58C in $20 \mathrm{mM}$ Tris, $\mathrm{pH} 7.2,75 \mathrm{mM}$

$\mathrm{NaCl}, 100 \mathrm{mV} / \mathrm{s}$ for $\mathrm{CV}$ scans, using a $\mathrm{Ag} / \mathrm{AgCl}$ reference electrode. 


\section{A}

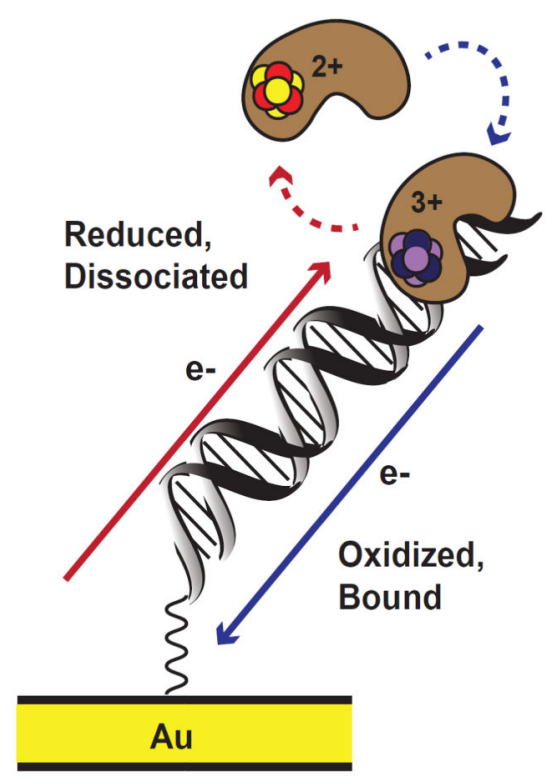

B
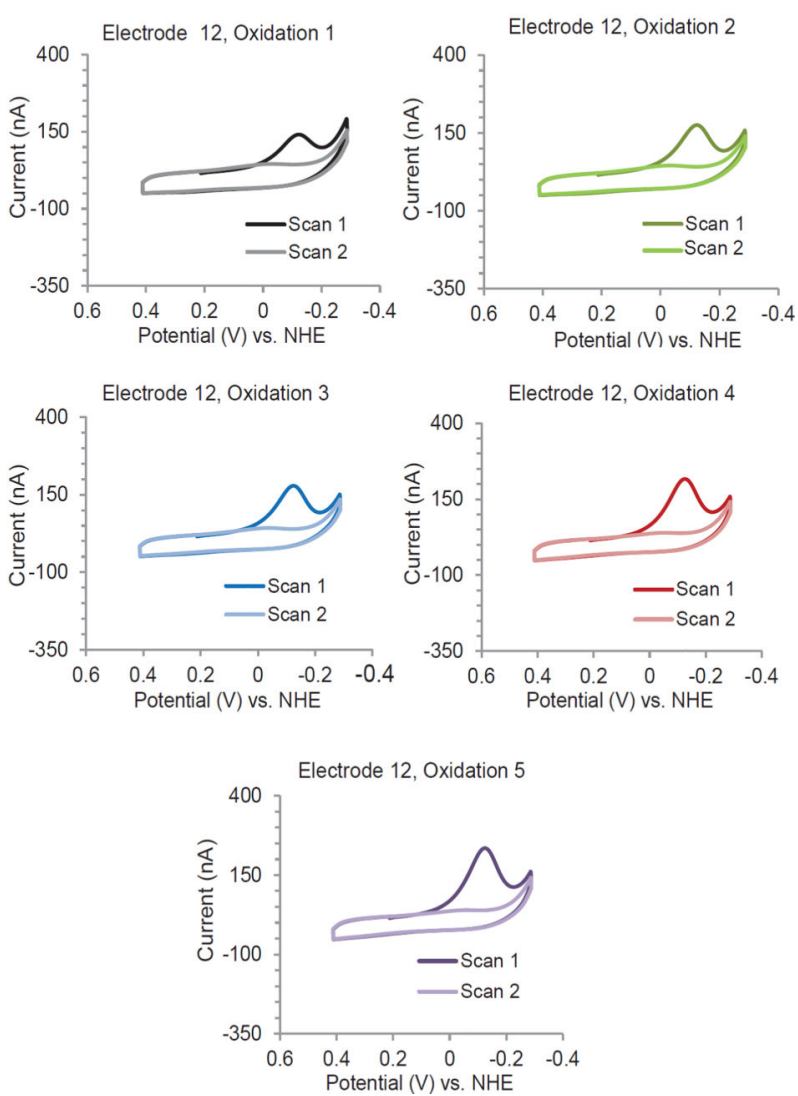

Figure 2. Iterative oxidation/reduction cycles of $\mathrm{p58C}$ on a single electrode surface

A) The scheme depicts the redox switch in p58C DNA binding. When oxidized, p58C is bound tightly to DNA. Reduction converts p58C to a weakly DNA-associated state. B) Cyclic voltammetry following five sequential oxidation reactions on one DNA-modified electrode of a multiplex chip. Electrolysis conditions ( $E_{\text {applied }}=412 \mathrm{mV}$ vs. NHE) are identical for each oxidation. A cathodic peak at ${ }^{-1} 130-{ }^{-} 140 \mathrm{mV}$ vs. NHE is regenerated each time in the first $\mathrm{CV}$ scan after oxidation. The cathodic peak corresponds to a reduction of tightly bound, oxidized p58C, to weakly associated p58C. Charge transfer values in the cathodic peaks for scans 1-5, in chronological order, are $65.4 \mathrm{nC}, 112.4 \mathrm{nC}, 116.4 \mathrm{nC}, 151.1$ $\mathrm{nC}$, and $170.9 \mathrm{nC}$. Peak charge increases over trials due to increasing $\mathrm{p} 58 \mathrm{C}$ at the solution/DNA interface. Electrochemistry was performed on $16 \mu \mathrm{M}$ p58C in $20 \mathrm{mM}$ Tris, $\mathrm{pH} 7.2,75 \mathrm{mM} \mathrm{NaCl}, 100 \mathrm{mV} / \mathrm{s}$ scan rate for $\mathrm{CV}$, using a $\mathrm{Ag} / \mathrm{AgCl}$ reference electrode. 
A

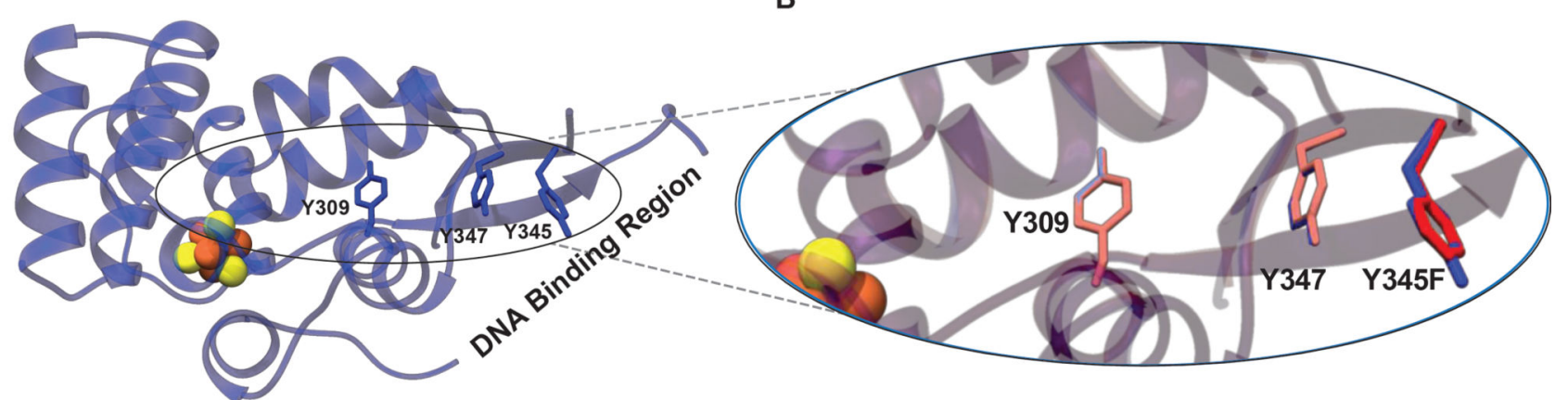

C

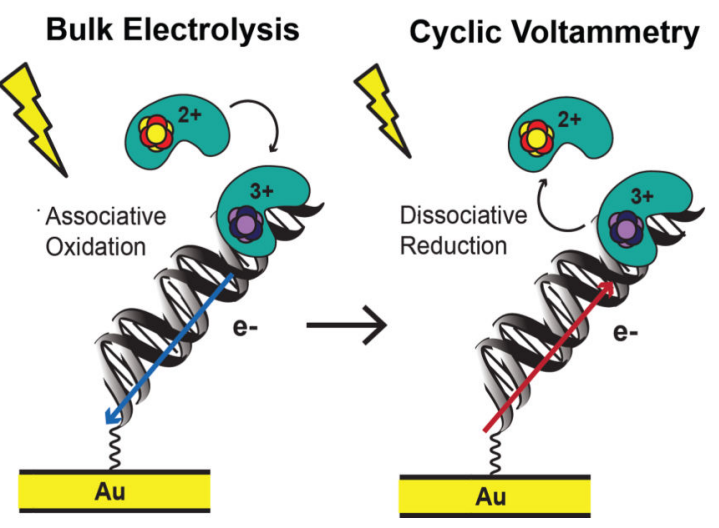

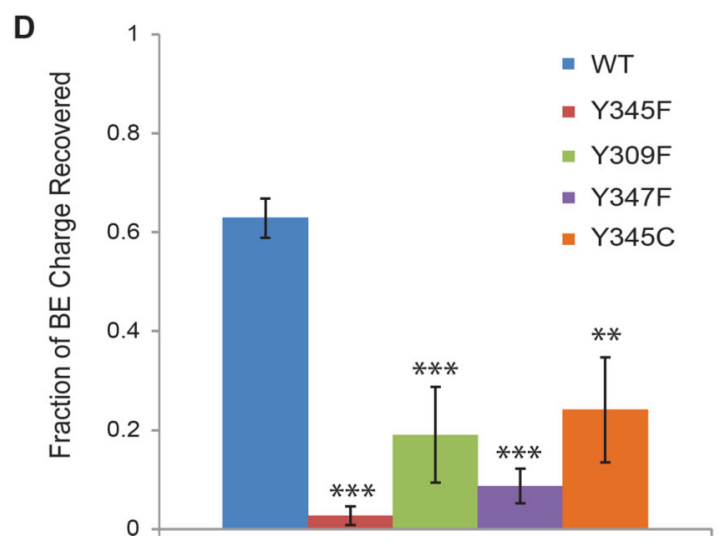

Figure 3. DNA-binding, charge-transfer deficient p58C mutants

A) Tyrosine residues conserved in eukaryotic primase [4Fe4S] domain (Y309, Y345, Y347

in H. sapiens, blue sticks) are located between the [4Fe4S] cluster (orange and yellow spheres) and DNA-binding region. The DNA binding region, consisting of residues R302, R306, K314, and W327, is located 20-30 ̊ from the cluster, necessitating electron transfer through the protein matrix for exchange of charge between the [4Fe4S] cofactor and bound DNA. B) Expanded region of the overlaid crystal structures of p58C (PDB 3L9Q, blue) and p58C Y345F (PDB 517M, red) demonstrates the minimal structural impact of the Y-F mutation; the phenylalanine residue in the mutant adapts the same orientation as the tyrosine in WT p58C. All mutants bind DNA with approximately the same affinity as WT p58C. C) Scheme depicts redox reactions in electrochemical assays with wild type and mutant p58C. Bulk electrolysis first oxidizes p58C and promotes tight DNA binding. CV then reduces the DNA-bound protein, converting it to the weakly associated, electrochemically inactive form. Both require the tyrosine charge transfer pathway and must be accounted for when comparing charge transfer proficiency. D) WT p58C recovers significantly more $(63 \pm 4 \%)$ bulk electrolysis charge than the mutants, suggesting that perturbation of the charge transfer pathway diminishes DNA-bound redox chemistry and consequently affects the redox switch. All bulk electrolysis reactions and CV scans were performed on $16 \mu \mathrm{M} \mathrm{p} 58 \mathrm{C} /$ mutant in 20 $\mathrm{mM}$ Tris, $\mathrm{pH} 7.2,75 \mathrm{mM} \mathrm{NaCl}$ at a $100 \mathrm{mV} / \mathrm{s}$ scan rate for $\mathrm{CV}$, using a $\mathrm{Ag} / \mathrm{AgCl}$ reference electrode. Mean $\pm \mathrm{SD}$ of $\mathrm{n}=3$ scans per variant, $* *=0.001<\mathrm{p}<0.0005, * * *=\mathrm{p}<0.0005$, student's t-test. 
A

\section{Primase Initiation}

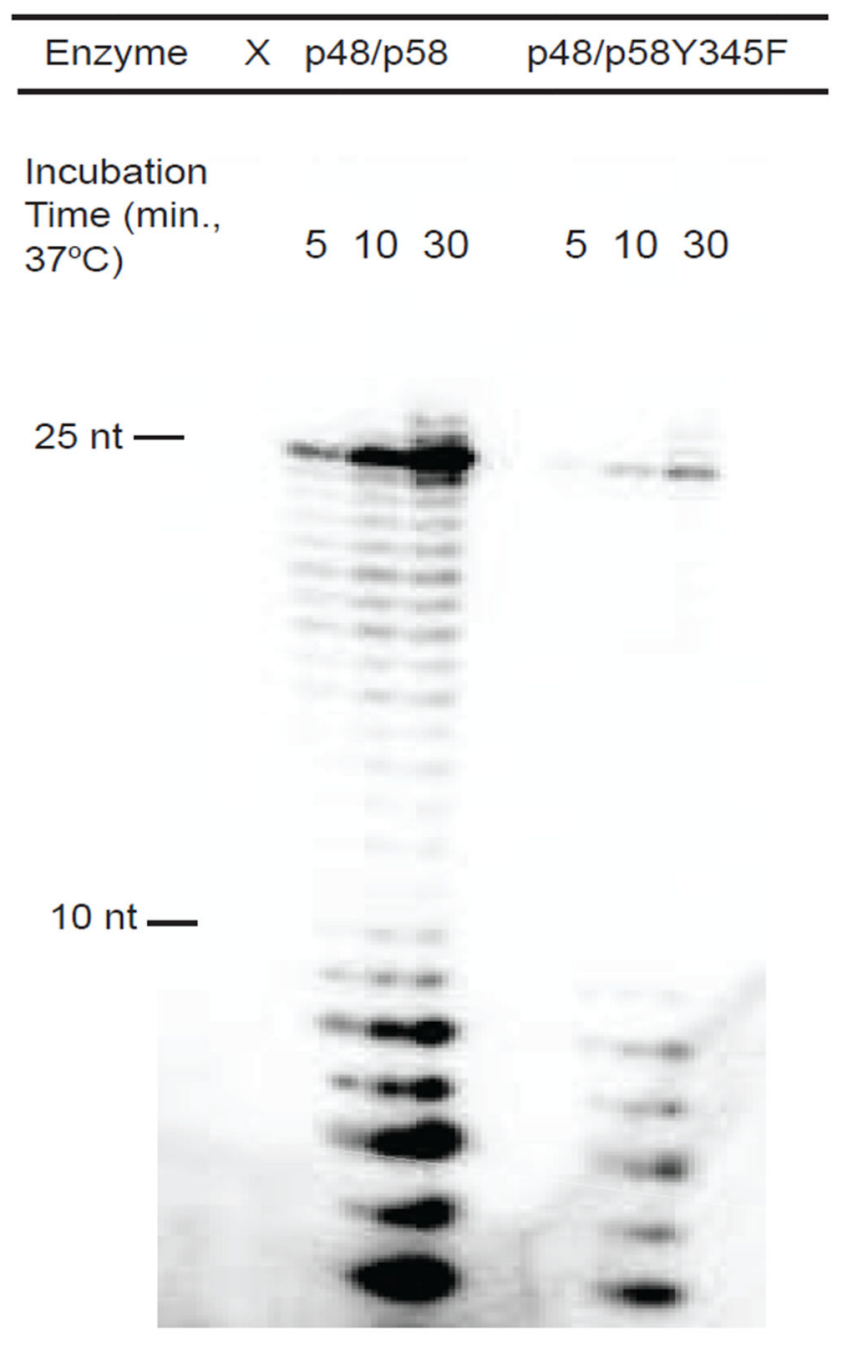

B
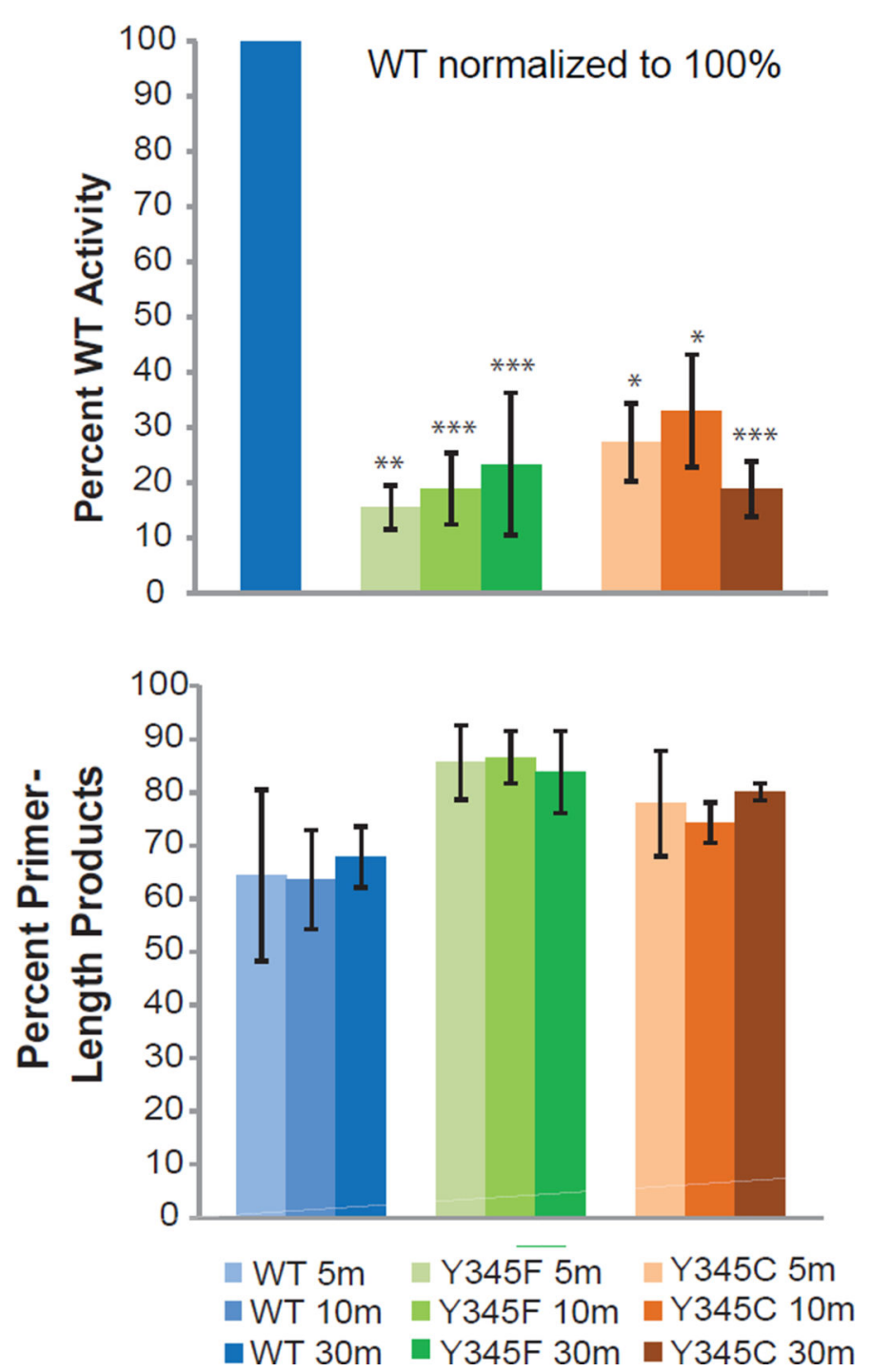

Figure 4. Redox Switching Plays a Role in Primase Initiation

A) Gel separation of products for WT p48/p58 and p48/p58Y345F reactions on ssDNA. The WT enzyme is significantly more active on ssDNA than either mutant. B) Quantified products for WT p48/p58, p48/p58Y345F, and p48/p58Y345C initiation assays. Mutants synthesize $15-35 \%$ of WT products on average. Mutant primase synthesizes shorter products on average. Primer-length products in graph below are defined as products 7-10nt in length. Initiation assays were performed anaerobically, with 250nM ssDNA, $1 \mu \mathrm{M} \mathrm{a}^{32} \mathrm{P}$ ATP, $112 \mu \mathrm{M}$ CTP, $188 \mu \mathrm{M}$ UTP, $400 \mathrm{nM}$ enzyme in $50 \mathrm{mM}$ Tris, $\mathrm{pH} 8.0,3 \mathrm{mM} \mathrm{MgCl}_{2}$, at $37^{\circ} \mathrm{C}$. Quantifications shown are mean \pm SD of $\mathrm{n} \geq 3$ trials, $*=0.001<\mathrm{p}<0.005$, ** $=$ $0.001<\mathrm{p}<0.0005, * * *=\mathrm{p}<0.0005$, student's t-test. 
A

Primase Elongation

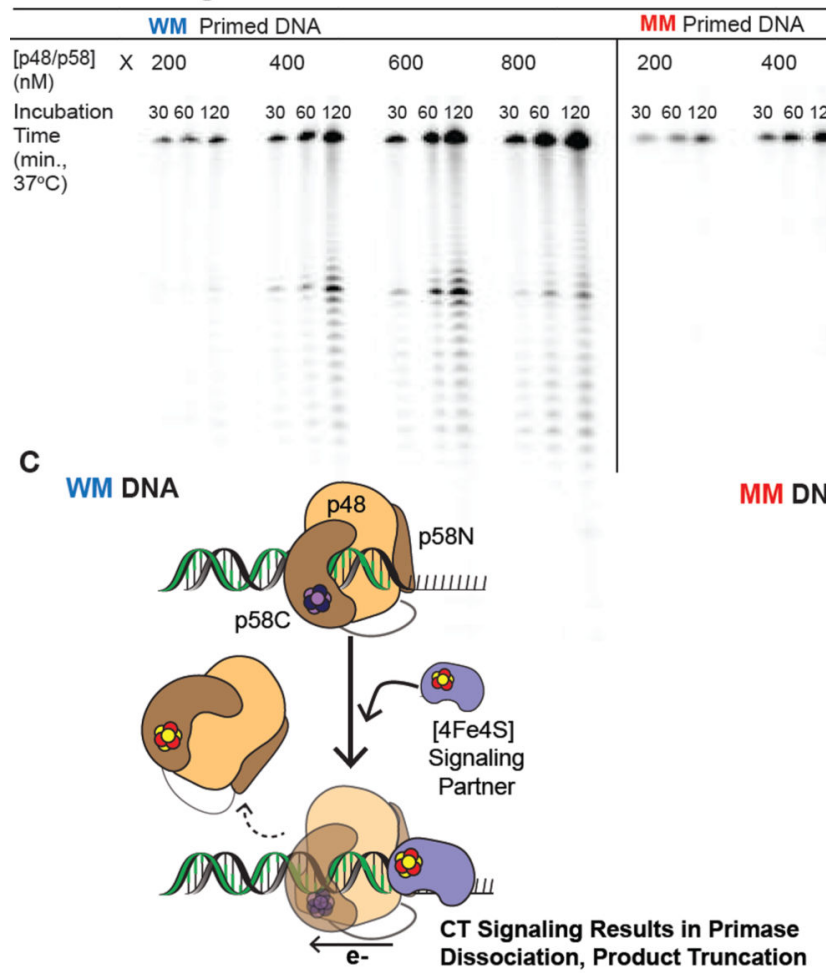

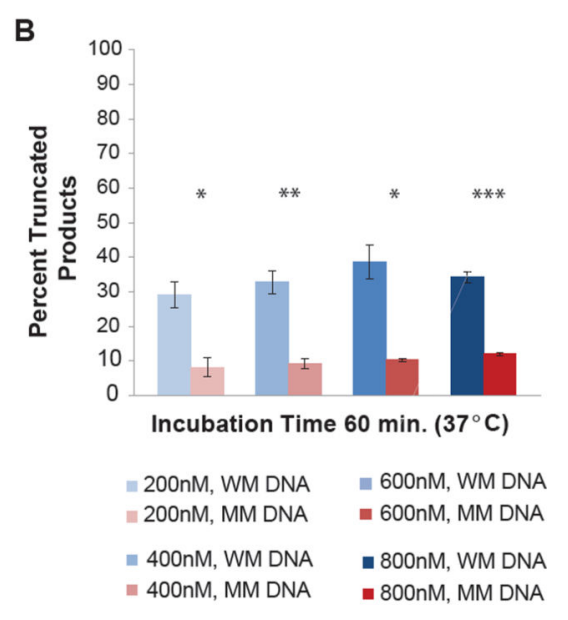

Figure 5. A Mismatch in the Nascent Primer Inhibits Primase Truncation

A) Gel separation of elongation products on a 2'-OMe RNA- primed DNA substrate, when a well-matched (WM) or mismatched (MM) primer is synthesized by WT p48/p58. B)

Average percent truncated products after 60 minutes of incubation at $37^{\circ} \mathrm{C}$. WT primase synthesizes significantly more truncated products with a WM primer than a MM primer. C) Scheme illustrating the observed products in the mismatched primer elongation experiment. When p58C is in contact with the RNA/DNA primer, primase can signal another DNAbound $[4 \mathrm{Fe} 4 \mathrm{~S}]$ enzyme through a WM primer and dissociate from the template, truncating products. bottom left) DNA CT is inhibited with a MM primer, precluding redox signaling and primer truncation. Elongation assays were performed anaerobically, with 500nM primed DNA, $1 \mu \mathrm{M} \mathrm{a-}{ }^{32}$ P ATP, $200 \mu \mathrm{M}$ CTP, $100 \mu \mathrm{M}$ UTP, 200-800 nM p48/p58 in $50 \mathrm{mM}$ Tris, $\mathrm{pH}$ 8.0, $3 \mathrm{mM} \mathrm{MgCl}_{2}$, at $37^{\circ} \mathrm{C}$. Quantifications shown are mean $\pm \mathrm{SD}$ of $\mathrm{n}=3$ trials, * $=$ $0.001<\mathrm{p}<0.005, * *=0.001<\mathrm{p}<0.0005, * * *=\mathrm{p}<0.0005$, student's t-test. 


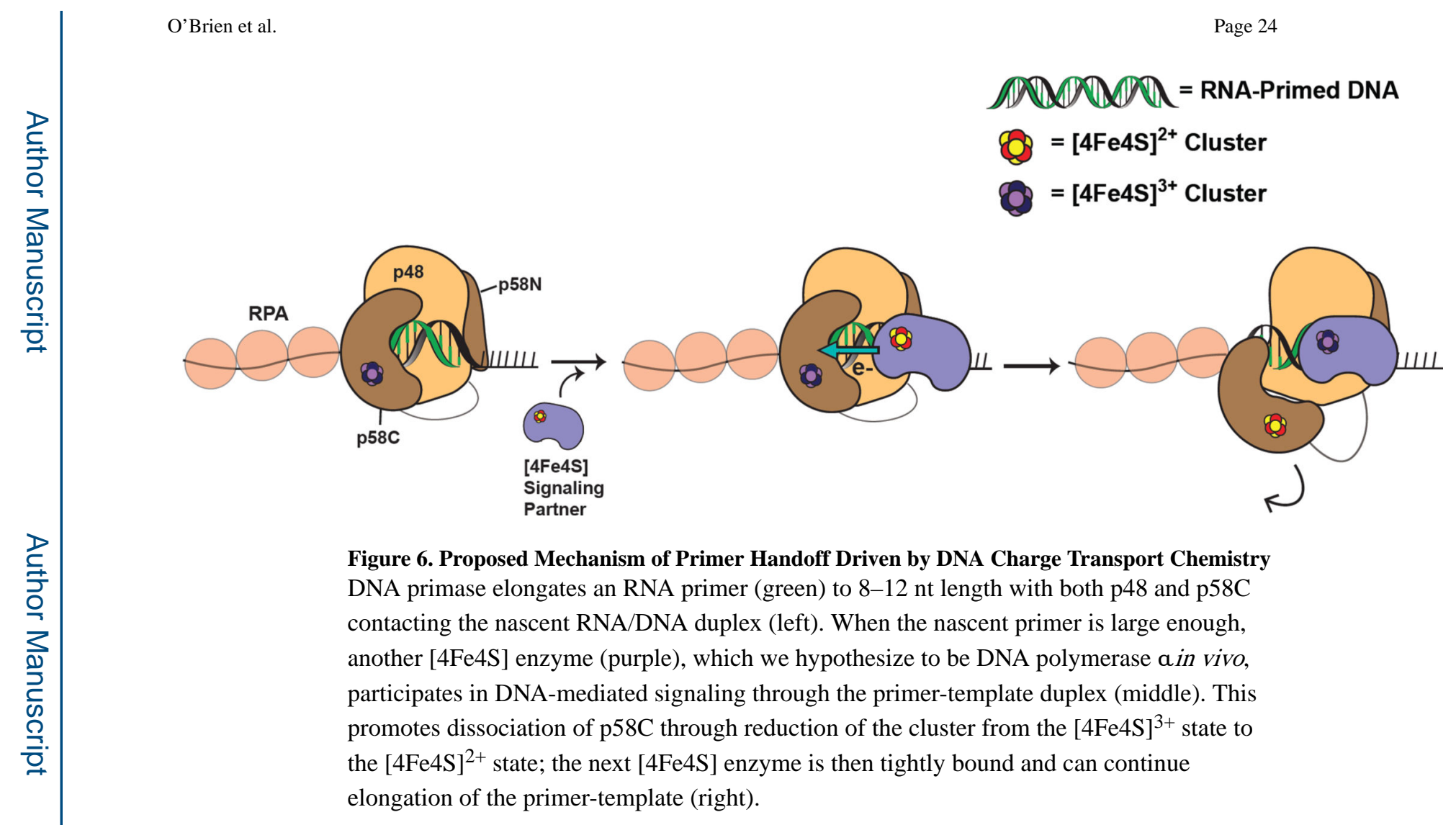

